\title{
Flood pulse and spatial dynamics of mercury in sediments in Puruzinho lake, Brazilian Amazon
}

\author{
Ronaldo de ALMEIDA' ${ }^{1,2}$, José Vicente Elias BERNARDI ${ }^{3}$, Ronaldo Cavalcante OLIVEIRA ${ }^{1}$, Dario Pires de \\ CARVALHO $^{1}$, Angelo Gilberto MANZATTO ${ }^{1}$, Luiz Drude de LACERDA ${ }^{4}$, Wanderley Rodrigues BASTOS ${ }^{*}$ \\ 1 Laboratório de Biogeoquímica Ambiental Wolfgang Christian Pfeiffer, Universidade Federal de Rondônia. Rodovia BR-364 km 9.5, CEP: 76815-800, Fone: (69) $2182-2122$. \\ Porto Velho, Rondônia, Brasil. wanderley@pq.cnpq.br / bastoswr@unir.br, ronaldorondonia@yahoo.com, darioilha@yahoo.com.br, manzatto@unir.br \\ * Corresponding Author: wanderley@pq.cnpq.br, bastoswr@unir.br \\ 2 Instituto de Natureza e Cultura, Ciências Agrárias e do Ambiente, Universidade Federal do Amazonas, Campus Benjamin Constant. Benjamin Constant, Amazonas, Brasil. \\ ronaldoufam@gmail.com \\ ${ }^{3}$ Departamento de Gestão Ambiental, Universidade de Brasília. Distrito Federal, Brasília, Brasil. bernardi@unb.br \\ ${ }^{4}$ Instituto de Ciências do Mar, Universidade Federal do Ceará. Fortaleza, Ceará, Brasil. Idrude@pq.cnpq.br
}

\begin{abstract}
The study was conducted in Puruzinho lake (Humaitá, AM) considering seasonal periods of rainy and dry in way to elucidate the flood pulse importance in the deposition, remobilization and distributions of mercury and organic matter in bottom sediments in the Madeira River Basin (Brazilian Amazon). Bottom sediments and soils samples were analyzed for total mercury and organic matter. Mercury concentrations obtained in bottom sediment were 32.20-146.40 ng g ${ }^{-1}$ and organic matter values were $3.5-18.0 \%$. The main region for accumulation of mercury and organic matter was in the central and deepest lake area In the rainy season there was a greater distribution of $\mathrm{Hg}$ and organic matter, mainly controlled by means of income of the Madeira river water during flooding, while the predominant process in the dry season was the remobilization of total Hg due to the resuspension of bottom sediments.
\end{abstract}

KEYWORDS: organic matter, indicator kriging, Madeira river, seasonality.

\section{O pulso de inundação e a dinâmica espacial do mercúrio em sedimentos no lago Puruzinho, Amazônia Brasileira}

\section{RESUMO}

Este estudo foi realizado no lago Puruzinho (Humaitá, AM) considerando os períodos de cheia e seca para investigar a importância do pulso de inundação na deposição, remobilização e distribuição das concentraçóes de mercúrio e matéria orgânica nos sedimentos de fundo no lago da bacia do rio Madeira, na Amazônia brasileira. As amostras de sedimentos e solos foram analisadas para mercúrio total e matéria orgânica. As concentraçóes mercúrio no sedimento de fundo variaram entre 32,20 e 146,40 $\mathrm{ng} \mathrm{g}^{-1}$ e as porcentagens de matéria orgânica variaram de 3,5 a 18,0\%. A principal região de acumulação de mercúrio e de matéria orgânica foi na área central e mais profunda do lago. Na estação chuvosa ocorreu maior distribuição de $\mathrm{Hg}$ e de matéria orgânica controlada principalmente pelo pulso de inundação do rio Madeira, enquanto que no período de seca predominam os processos de remobilizaçáo de mercúrio devido a resssuspensão do sedimento de fundo.

PAVRAS-CHAVE: matéria orgânica, krigagem indicativa, rio Madeira, sazonalidade. 


\section{INTRODUCTION}

Gold mining of alluvial sediments using amalgamation is one of the greatest contributions for the Amazon mercury (Hg) contamination (Pfeiffer and Lacerda 1988; Pfeiffer et al. 1991; Malm 1998). This is followed by deforestation and forest burning (Lacerda 1995), degassing from soils (Almeida et al. 2005) together with loss by soil erosion (Roulet et al.1999; Roulet et al. 2000). These factors are all present in the Madeira river basin. Alluvial gold mining on the Madeira river reached its peak between 1980 and 1990. It is estimated that from 1979 to 1985 , about 100 tons of $\mathrm{Hg}\left(12.4 \mathrm{t} \mathrm{yr}^{-1}\right)$ were discharged into the Madeira river basin (Lacerda et al.1989) and this amount remained constant through the early 1990's, decreasing to less than $0.5 \mathrm{t} \mathrm{yr}^{-1}$ after 1995 (Lacerda et al. 2012). In recent years, gold mining in the Madeira river has declined, however the activity still contributes significantly to the amount of mercury discharged into this ecosystem, mostly from gold mining on the Beni and Madre de Dios rivers (Bastos et al. 2006).

Burning of forests, extensive cattle ranching, soybean plantations and cassiterite mining (tin ore) in these hydrographic basins lead to the erosion of soils, which are naturally enriched in mercury (Lechler et al. 2000; Almeida et al. 2005). Thus, the Madeira river and its tributaries act as the principal route in exporting $\mathrm{Hg}$ to their associated aquatic systems (Gomes et al. 2006). Approximately 25\% of the sediment stored in the lower Amazon river originates from the Madeira river basin (Filizola-Junior 1999; Latrubesse et al. 2005).

The remobilized sediment originating in the Andean regions and high areas of the upper Madeira is transported by the Madeira's principal system (Filizola-Junior 1999) and deposited in the areas of accumulation and flooding of the lower Madeira river. The $\mathrm{Hg}$ concentration in vertical profiles of bottom sediment in lakes of the lower Madeira river basin indicates the accumulation of this element over time (Bastos et al. 2006). Vergotti et al (2009) showed significative correlation $(\mathrm{r}=0.78)$ between mercury and organic matter in bottom sediments of lakes of the Madeira river basin.

Lechler et al. (2000) considered that the Madeira river basin is influenced by both natural and anthropic processes. Junk (1985) studied the flood pulse in the areas comprising the Amazon basin and established ecological relations between the terrestrial and aquatic systems. Flood areas, therefore, play a crucial role in the exportation and importation of pollutants, as is the case in the lake systems of the Madeira river (Almeida 2006; Bastos et al. 2007).

The deposition and remobilization of $\mathrm{Hg}$ combined with the physicochemical characteristics favorable for methylation present in flood plain lakes sediments, and, in particular, the organic matter concentration and it sources, flooded soils and river waters inundating the lakes, may have direct implications on the accumulation of $\mathrm{Hg}$ in the first links of the food chain and on the exposure of humans through fish consumption. In this context the present study aimed evaluated the spatial dynamics of mercury distribution and organic matter in bottom sediments of the Puruzinho lake (Brazilian Amazon).

\section{MATERIALS AND METHODS}

The Puruzinho lake, Madeira river tributary, is localized in the area of the low uplands of western Amazonia, comprising the areas called flood and accumulation areas (HAi) consisting of undifferentiated or ancient alluvia (Figure 1).

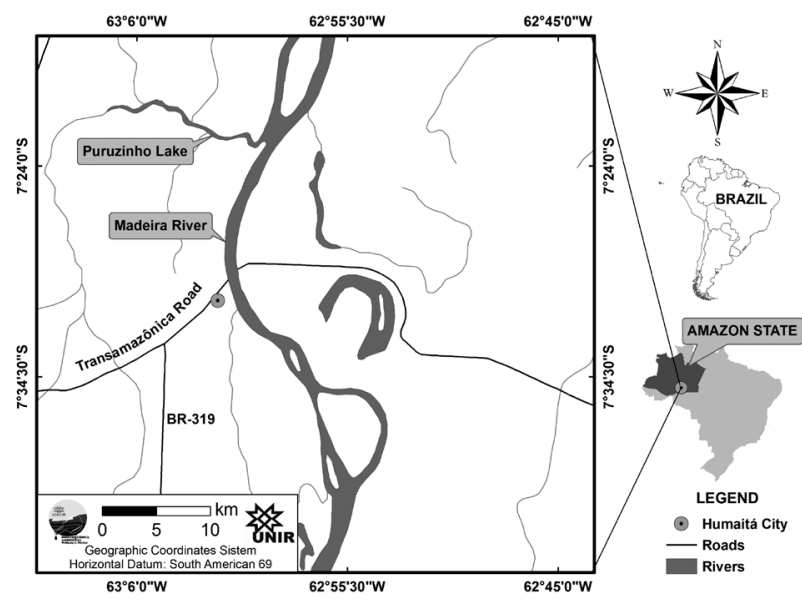

Figure 1 - Location of the study area.

Bottom sediments were collected during the period of rainy season $(n=30$, February 2004) and during the dry season ( $n=30$, August 2005) in 11 transects as proposed by Bernardi et al. (2001). Soil samples were collected in the dry season. The bottom sediment samples were collected with an Eckman dredge and acrylic tube for vertical profiles of $50 \mathrm{~cm}$. The physicochemical parameters ( $\mathrm{pH}$, electrical conductivity, dissolved oxygen, water temperature and depth) were also measured in situ at all sampling points (Horiba - model U10, Japan).

The soil samples were collected in the dry season (August 2005) using a dutch drill. The organic layer of the soil was sampled at depths varying from 1 to $7 \mathrm{~cm}$ and the inorganic layer at depths of 7 to $20 \mathrm{~cm}$. A total of 13 points distributed equidistantly along the left and right banks of the lake were sampled.

The soil and bottom sediment samples were subjected to a gravimetric process reducing them to a fraction of less than $0.075 \mathrm{~mm}$ (200 mesh). The samples were then oven-dried at 40 ${ }^{\circ} \mathrm{C}$, macerated and stored in polyethylene jars until they were 
analyzed. To determine the total $\mathrm{Hg}$, samples of about $\mathrm{lg}$ (dry weight) were digested on hot plate at $80^{\circ} \mathrm{C}$ with a $\mathrm{HCl}: \mathrm{HNO}_{3}$ (3:1) mixture and strongly oxidized with $\mathrm{KMnO}_{4}(5 \%)$. They were then filtered by gravity through a cellulose filter (Whatman 44, New Jersey, USA). The total Hg of the samples was determined by atomic absorption spectrophotometry coupled to a cold vapor generator (FIMS-400, Perkin-Elmer, Germany) (Bastos et al. 1998). The analytical quality was controlled using control blanks, replicates of each sample, and certified reference samples International Atomic Energy Agency (IAEA-356, Vienna, Austria). The content of organic matter in the soil and bottom sediment samples was quantified by the ignition method (Kalra and Maynard 1991).

This study employed geoprocessing techniques based on geostatistics that allow for the superposition of base maps and mapped surfaces using geostatistical methods and indicator kriging. The geostatistical method, which is described in detail by Isaaks and Srivastava (1989), is based on the theory of regionalized variables (Matheron 1971; Landim 1998; Markus and McBratney, 2001). To interpret the data, a GIS (Geographic Information System) was built using ArcGIS 9.0 software. The variographic analysis was carried out using the "Geostatistical Wizard" module of ArcGIS 9.0.

\section{RESULTS}

Physicochemical parameters were affected by the hydrological regime between the rainy and dry seasons (Table 1). During the high water period, the lake reaches a mean depth of $11 \mathrm{~m}$, the water is more acid and the concentration of dissolved oxygen is low $(\mathrm{p}<0.05 ; \mathrm{n}=30)$.

Mercury concentrations in bottom sediment varied from 32.20 to $146.40 \mathrm{ng} \mathrm{g}^{-1}$. The percentage of organic matter in the bottom sediment ranged from 3.5 to $18 \%$. However, the mean values showed no significant difference $(\mathrm{p}<0.05 ; \mathrm{n}=29)$ between the low and high water periods (Table 2).

Table 1 - Descriptive statistics of the limnological parameters in the rainy and dry seasons.

\begin{tabular}{lcc}
\hline \multirow{2}{*}{ Parameters } & $\begin{array}{c}\text { Rainy Season } \\
(\mathrm{n}=30)\end{array}$ & $\begin{array}{c}\text { Dry Season } \\
(\mathrm{n}=30)\end{array}$ \\
\cline { 2 - 3 } & $\begin{array}{c}\text { Mean } \pm \mathrm{SD} \\
(\text { Interval range) }\end{array}$ & $\begin{array}{c}\text { Mean } \pm \mathrm{SD} \\
\text { (Interval range) }\end{array}$ \\
\hline $\mathrm{pH}$ & $4.97 \pm 0.23$ & $5.48 \pm 0.32$ \\
& $(4.66-5.85)$ & $(5.00-6.70)$ \\
Oxygen Dissolved $\left(\mathrm{mg} \mathrm{L}^{-1}\right)$ & $3.40 \pm 0.31$ & $5.42 \pm 0.49$ \\
& $(2.69-3.82)$ & $(4.79-6.50)$ \\
Water Temperature $\left({ }^{\circ} \mathrm{C}\right)$ & $29.80 \pm 1.30$ & $30.90 \pm 1.60$ \\
& $(28.00-32.30)$ & $(28.70-35.70)$ \\
Depth $(\mathrm{m})$ & $11.00 \pm 0.90$ & $0.90 \pm 0.60$ \\
& $(8.00-12.50)$ & $(0.30-2.30)$ \\
Electrical Conductivity $\left(\mathrm{mS} \mathrm{cm}^{-1}\right)$ & $8.36 \pm 0.68$ & $14.27 \pm 0.63$ \\
& $(7.50-11.00)$ & $(12.70-16.10)$ \\
\hline
\end{tabular}

Table 2 - Descriptive statistics of mercury concentrations $\left(\mathrm{ng} \mathrm{g}^{-1}\right)$, percentage of organic matter (\%) and range in bottom sediment and soil from the Lake Puruzinho.

\begin{tabular}{|c|c|c|c|c|}
\hline Samples & Seasonality & $n$ & $\begin{array}{c}{[\mathrm{Hg}]\left(\mathrm{ng} \mathrm{g}^{-1}\right)} \\
\text { (Interval Range) }\end{array}$ & $\begin{array}{c}{[\mathrm{OM}]} \\
(\%)\end{array}$ \\
\hline Sediment Profile 1 & Rainy season & 10 & $\begin{array}{c}53.30 \\
(27.80-93.30)\end{array}$ & - \\
\hline Sediment Profile 2 & Rainy season & 10 & $\begin{array}{c}38.70 \\
(26.40-43.90)\end{array}$ & - \\
\hline Sediment Profile 3 & Rainy season & 10 & $\begin{array}{c}54.10 \\
(33.80-73.00)\end{array}$ & - \\
\hline Bottom Sediment & Rainy season & 29 & $\begin{array}{c}84.20 \\
(44.00-129.10)\end{array}$ & $\begin{array}{c}7.88 \\
(3.42-14.43)\end{array}$ \\
\hline Bottom Sediment & Dry season & 29 & $\begin{array}{c}71.20 \\
(32.20-146.40)\end{array}$ & $\begin{array}{c}8.40 \\
(3.49-17.95)\end{array}$ \\
\hline Soil layer $\mathrm{HO}$ & Dry season & 11 & $\begin{array}{c}53.50 \\
(22.40-66.90 .)\end{array}$ & - \\
\hline Soil layer HA & Dry season & 16 & $\begin{array}{c}66.70 \\
(22.40-120.70)\end{array}$ & - \\
\hline
\end{tabular}

The spatial analysis of mercury and organic matter using the geostatistical technique of variography was adjusted to a variographic model adjusted to mercury, which was a Gaussian model. The maximum range obtained for mercury distribution was $3.960 \mathrm{~m}$, while the organic matter distribution model attained a maximum range of $4,350 \mathrm{~m}$, demonstrating a correlation between organic matter and its neighboring values. Thus, the points of the sampled grid in the process of interpolation by indicator kriging were used.

The models of the distributions of $\mathrm{Hg}$ and organic matter concentrations both presented the nugget effect, indicating a slight discontinuity at the origin. The anisotropy was strongly oriented towards the lake's principal axis, since the length of the lake's transversal axis is contained about 10 times in the length of the lake.

The results of the application of indicator kriging for $\mathrm{Hg}$ (Figure 2 in $\mathrm{A}$ and $\mathrm{C}$ ) and organic matter (Figure 2 in $\mathrm{B}$ and $\mathrm{D})$.

The results of the application of indicator kriging for $\mathrm{Hg}$ and organic matter are discussed as follows. The cutoff values were estimated by the median $>67.13 \mathrm{ng} \mathrm{g}^{-1}$ and $8 \%$ for $\mathrm{Hg}$ and organic matter, respectively. The spatial variability of the data on $\mathrm{Hg}$ and organic matter in Puruzinho lake demonstrates compartmentalization of the lake in terms of the presence of $\mathrm{Hg}$ and organic matter (Figure 2). The diagrams of distribution probability indicate the preferential areas of accumulation of $\mathrm{Hg}$ and organic matter. The distribution pattern of $\mathrm{Hg}$ in the bottom sediment demonstrates that an expansion of the area occurs in relation to the area of distribution of $\mathrm{Hg}$ in the dry season (Figure 2A and 2B). These areas correspond to the deepest regions of the lake. However, the organic matter is spatially more evenly distributed in the dry season (Figure $2 \mathrm{C}$ and $2 \mathrm{D}$ ). 

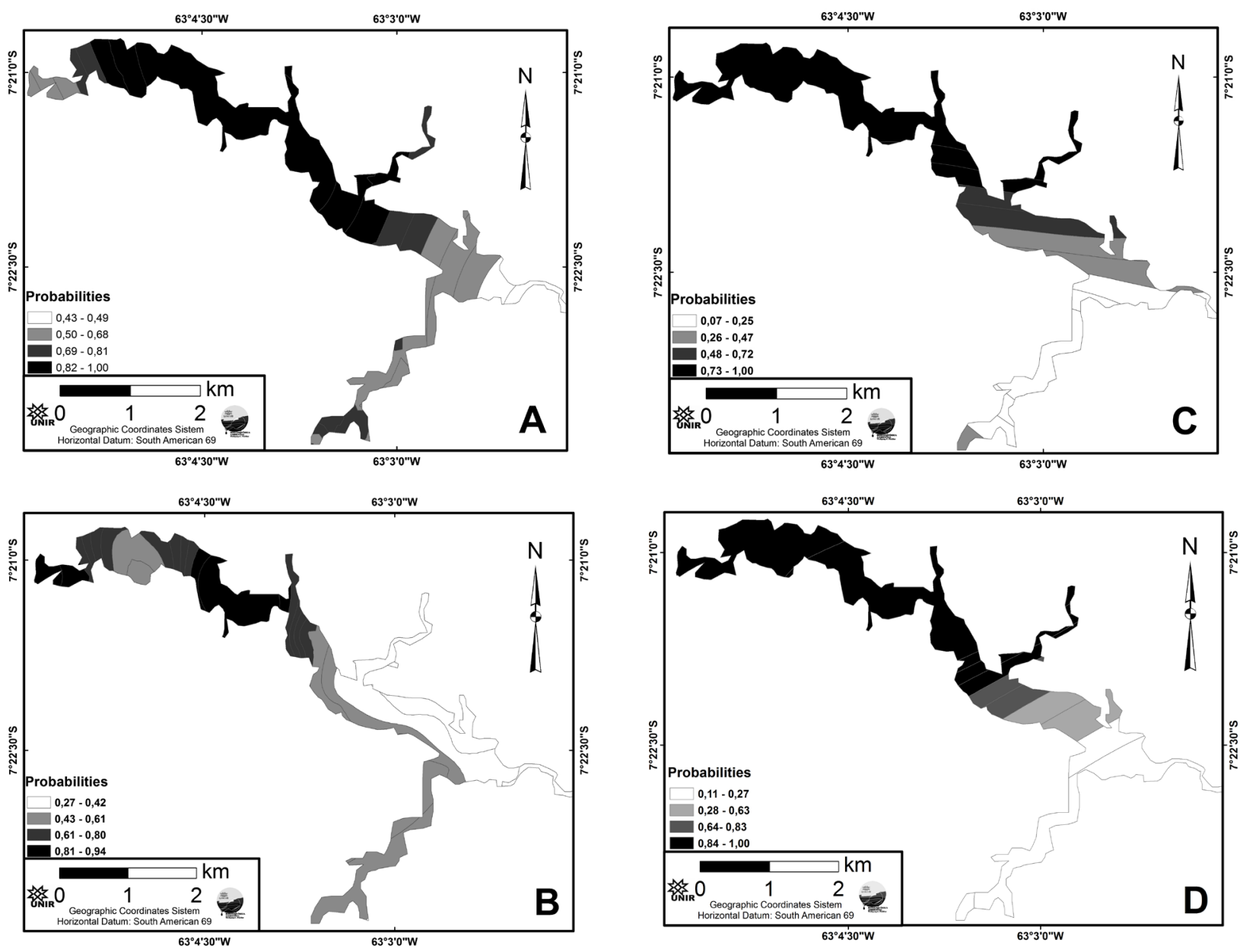

Figure 2 - Diagram of probability distribution (cutoff $>67.13 \mathrm{ng} \mathrm{g}^{-1}$ for $\mathrm{Hg}$ and $8 \%$ for organic matter). A and $\mathbf{C}$ for mercury and $\mathbf{B}$ and $\mathbf{D}$ for organic matter, rainy and dry seasons, respectively.

The values of the vertical profile upstream in the lake show a higher $\mathrm{Hg}$ concentration peaking at a depth of 15 $\mathrm{cm}$, followed by a decrease at depths below $20 \mathrm{~cm}$ (Profile 1). The central portion of the lake showed higher values at the surface than the other profiles. The profile in the central part of the lake is situated in the region mapped as the area of highest concentration, indicating temporal deposition (Profile 2). The wide variation in the $\mathrm{Hg}$ values in sediment profiles may be related to recent superficial enrichment of the bottom sediment or to bioturbation processes in the first layers of the sediment (Profile 3) (Table 2).

At the sampled points, the organic layer presented lower values than those obtained from the layer situated at a depth of $10-20 \mathrm{~cm}$ (Figure 3). The first layer is composed of litter and an organic horizon ( $\mathrm{HO})$, while the second and lower layer is the surface mineral horizon (HA) composed of soils formed from recently deposited sediments.

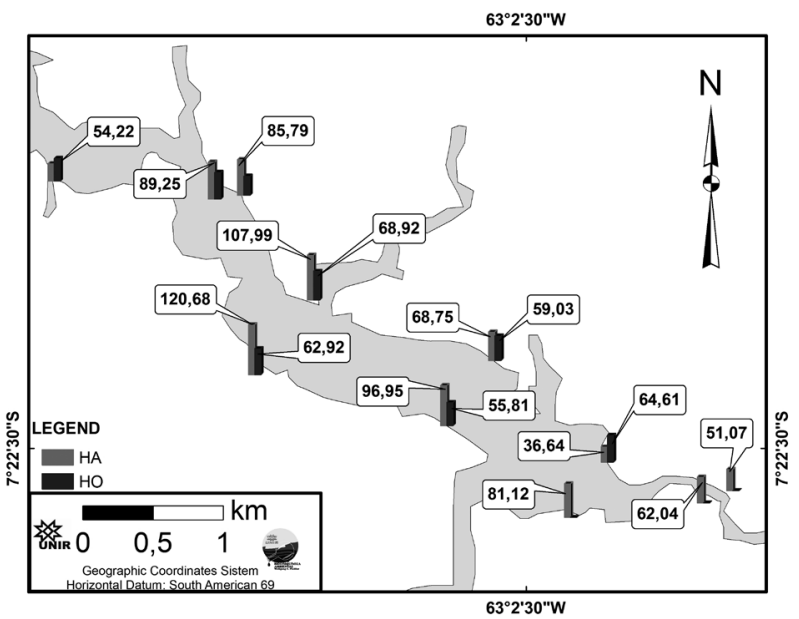

Figure 3 - Mercury concentration $\left(\mathrm{ng} \mathrm{g}^{-1}\right)$ in soils along the banks of Puruzinho lake in the dry season $(\mathrm{HA}=$ Layer varying from $7-20 \mathrm{~cm}$ depth; $\mathrm{HO}=$ Soil surface layer rich in organic matter). 
Table 3 - Mercury concentration ( $\mathrm{ng} \mathrm{g}^{-1}$ ) in bottom sediment from the Madeira River and marginal lakes.

\begin{tabular}{lcl}
\hline \multicolumn{1}{c}{ Locality } & $\begin{array}{c}{[\mathrm{Hg}]} \\
\left(\mathrm{ng} \mathrm{g}^{-1}\right)\end{array}$ & References \\
\hline $\begin{array}{l}\text { Puruzinho lake } \\
\text { (Rainy Season) }\end{array}$ & $44.02-129.00$ & This work \\
\hline $\begin{array}{l}\text { Puruzinho lake } \\
\text { (Dry Season) }\end{array}$ & $32.20-146.40$ & This work \\
\hline Cuniã lake & $66.20-117.10$ & Bastos et al. (2006) \\
\hline Paraíso lake & $26.00-71.80$ & Bastos et al. (2006) \\
\hline Santo Antônio lake & $46.90-74.70$ & Bastos et al. (2006) \\
\hline Mergulhão lake & $73.00-109.00$ & Bastos et al. (2006) \\
\hline Acará lake & $36.50-60.00$ & Bastos et al. (2006) \\
\hline Matupirizinho lake & $35.10-99.10$ & Bastos et al. (2006) \\
\hline Preto lake & $54.40-70.00$ & Bastos et al. (2006) \\
\hline Madeira river & $40.00-53.60$ & Bastos et al. (2006) \\
\hline Madeira river & $50.00-280.00$ & Pfeiffer et al. (1989) \\
\hline Mutum Paraná river & $210.00-19,800.00$ & Pfeiffer et al. (1989) \\
\hline
\end{tabular}

\section{DISCUSSION}

The hydrodynamics of Puruzinho lake, like that of all Amazonian lakes, is influenced by the flood pulse. The lakes in the Madeira river basin are subject to the deposition of suspended materials rich in adsorbed $\mathrm{Hg}$ due to a phenomenon known as "repiquete" - the swell of rising waters from the Madeira river that enter the Amazonian lakes, even the most distant ones, as in the case of Puruzinho lake (about $8 \mathrm{~km}$ distant), acting as deposits of $\mathrm{Hg}$ transported by the principal river or generated by processes that occur locally, such as runoff and burning along their banks. Bastos et al. (2006) demonstrate that the lakes in this region have a higher $\mathrm{Hg}$ concentration than the Madeira river (Table 3). The $\mathrm{Hg}$ concentrations found in bottom sediments of the Madeira river and its tributaries are lower than those found by Pfeiffer et al. (1989) at the peak of gold mining on the Madeira river (Table 3). Factors such as the reduction of $\mathrm{Hg}$ emissions from gold mining, methylation, together with the exportation of this metal to other regions such as floodplains may contribute to the reduction of concentrations of $\mathrm{Hg}$ in the bottom sediment.

The probability diagrams for $\mathrm{Hg}$ and organic matter generated by the indicator kriging technique demonstrate the formation of preferential areas of concentration in the central portion of Puruzinho lake. A comparison of the probability surfaces generated, using as cutoff value a higher concentration than the median $63.20 \mathrm{ng} \mathrm{g}^{-1}$, indicates that the central portion of the lake presents the highest probability of this value occurring. A similar pattern can also be observed for the organic matter, considering a higher than $8 \%$ cutoff value. Note, also, that there is a slight change in the preferential areas of $\mathrm{Hg}$ and organic matter concentration in the rainy and dry seasons. Roulet et al. (2001) suggest that the production of $\mathrm{MeHg}$ is favored during the high water period in comparison with the consumption of $\mathrm{MeHg}$. In the present study, it was found that during the period of high water (rainy season), the areas of higher $\mathrm{Hg}$ concentrations expanded in relation to the dry season.

The central part of the lake constitutes its deepest region, so the removal of $\mathrm{Hg}$ and organic matter may be more difficult. The concentration of $\mathrm{Hg}$ in Puruzinho lake is a consequence of burning vegetation close to the lake's headwaters and of transportation and deposition by the Madeira river (swell of rising water caused by heavy rainfall in the region of the headwaters). The Madeira river carries high loads of suspended solids rich in adsorbed $\mathrm{Hg}$ (Maurice-Bourgoin et al. 2003) from anthropogenic processes generated throughout the Madeira river basin, such as gold mining and land occupation for agriculture (Gomes et al. 2006).

The $\mathrm{Hg}$ transported in suspended solids is discharged by gold mining into both the Beni river and the upper Madeira river and by soil erosion in the sub basins of the Madeira's tributaries. The inversion of the fluviometric level during high water is an important factor in the distribution pattern of $\mathrm{Hg}$ in sediment (Meade et al. 1985). Mercury deposited during high water is incorporated into a sediment rich in allochthonous organic matter. Under anaerobic conditions, inorganic $\mathrm{Hg}$ may be converted into $\mathrm{MeHg}$ - and can be incorporated by detrivorous organisms, entering the food chain, where it biomagnifies (Watras and Bloom 1992). The retraction of the areas of highest $\mathrm{Hg}$ concentration indicates the remobilization of $\mathrm{Hg}$ and, hence, its exportation to other areas during the dry season.

The vertical distribution patterns of $\mathrm{Hg}$ concentrations in the sediment profiles indicate a wide variation in $\mathrm{Hg}$ concentrations in the sediment, possibly resulting from fluctuations in deposition due to the period when $\mathrm{Hg}$ was discharged into the Madeira river basin. The central part of the lake is the area where the highest deposition occurred. Because this area is the deepest region of the lake, it contains higher concentrations of organic matter and is more directly influenced by the fluviometric level of the Madeira river. This area is where the lowest remobilization of $\mathrm{Hg}$ occurs, and is also the area most directly related with dry-land soils.

\section{CONCLUSION}

The $\mathrm{Hg}$ deposition process in rainy season are mainly dominated by means of income of organic matter and suspended solids transported by the Madeira river flooding, while the predominant process in the dry season is the 
remobilization of total $\mathrm{Hg}$ due to the resuspension of bottom sediment .

$\mathrm{Hg}$ concentrations in lake sediments based on indicator kriging, showed that the total concentration of $\mathrm{Hg}$ and of organic matter in bottom sediment vary spatially, depending on the concentrations of the samples collected in the proximities. Thus, $\mathrm{Hg}$ and organic matter form compartments in the lake, creating coinciding preferential zones of concentration of $\mathrm{Hg}$ and organic matter.

\section{ACKNOWLEDGEMENTS}

This work was funded by Conselho Nacional de Desenvolvimento Científico e Tecnológico-CNPq, (PPG-7 Project, process 556934/2005-9 and 556972/2005-8; CNPq/ CT-Biotecnologia Project, process 553269/2005-4). The authors are deeply indebted to the Puruzinho community for the important information they provided and logistic assist extended to the Laboratório de Biogeoquimíca Ambiental team. Thanks to Igor Bruno B. de Holanda and Nicholas Richardson for correcting the figures and English, respectively.

\section{REFERENCES}

Almeida, M.D.; Lacerda, L.D.; Bastos, W.R.; Herrmann, J.C. 2005. Mercury loss from soils following conversion from forest to pasture in Rondonia, Western Amazon, Brazil. Environmental Pollutan, 137: 179-186.

Almeida, R. 2006. Analise geoestatística das concentraçôes de mercúrio no lago Puruzinho - Amazônia Ocidental. Dissertação de Mestrado, Núcleo de Ciência e Tecnologia/Fundaçáo Universidade Federal de Rondônia, Porto Velho, Rondônia. 84p.

Bastos, W.R.; Malm, O.; Pfeifer, W.C.; Cleary, D. 1998. Establishment and analytical quality control of laboratories for $\mathrm{Hg}$ determination in biological and geological samples in the Amazon Brazil. Ciência e Cultura, 50: 255 - 260.

Bastos W.R.; Gomes J.P.O.; Oliveira R.C.; Almeida R.; Nascimento E.L.; Bernardi J.V.E.; Lacerda L.D.; Silveira E.G.; Pfeiffer W.C. 2006. Mercury in the environment and riverside population in the Madeira River Basin, Amazon, Brazil. Science of the Total Environment, 368: 344-351.

Bastos W.R.; Almeida R.; Dorea J.G.; Barbosa A.C. 2007. Annual flooding and fish-mercury bioaccumulation in the environmentally impacted Rio Madeira (Amazon). Ecotoxicology, 16: 341-346.

Bernardi J.V.E.; Fowler H.G.; Landim P.M.B. 2001. Um estudo de impacto ambiental utilizando análise estatística espacial e multivariada. Holos Environment, 1: 162 - 172.

Filizola-Junior N.P. 1999. O fluxo de sedimentos em suspensão nos rios da bacia Amazônica Brasileira. ANEEL, Brasília, DF. 1999.63p.

Gomes J.P.O.; Nascimento E.L.; Almeida R.; Bastos W.R.; Bernardi J.V.E.; Barros P.R.H.B. 2006. Distribuição Espacial das Concentrações de Mercúrio em sólidos em suspensão no alto rio Madeira. Journal of the Brazilian Society of Ecotoxicology, 1: 131-135.

Isaaks E.H.; Srivastava R.M. 1989. An Introduction to Applied Geostatistics. Oxford University Press, New York. 1989. 561p.

Junk W.J. 1985. Temporary Fat Storage an Adaptation of Some Fish Species to the Water level Fluctuation and Related Environmental Changes of the Amazon River. Amazoniana, 11: 315-35.

Kalra Y.P.; Maynard D.G. 1991. Methods manual for forest soil and plant analysis. Forestry Canada Northwest Region, Northern Forest Centre. Edmonton, Alberta. Canada. 116p.

Lacerda, L.D.; Pfeiffer, W.C.; Ott, A.T.; Ssilveira, E.G. 1989. Mercury contamination in the Madeira river, Amazon. Hg inputs to the environment. Biotropica, ,21: 91-93.

Lacerda L.D. 1995. Amazon mercury emissions. Nature, 374: 20-21.

Lacerda L.D.; Bastos W.R.; Almeida M.D. 2012. The impacts of land use changes in the mercury flux in the Madeira River, Western Amazon. Annals of the Brazilian Academy of Sciences, 84: 73-82.

Landim P.M.B. 1998. Análise estatística de dados geológicos. Ed. UNESP, São Paulo. 1998. 225p.

Latrubesse E.; Stevaux J.; Sinha R. 2005. Tropical rivers. Geomorphology, 70: 187-206.

Lechler P.J.; Miller J.R.; Lacerda L.D.; Bonzongo D.J.C.; Lyons W.B.; Warwick J.J. 2000. Elevated mercury concentrations in soils, sediments, water, and fish of the Madeira River basin, Brazilian Amazon: a function of natural enrichments? Science of the Total Environment, 260: 87-96.

Malm O. 1998. Gold mining as a source of mercury exposure in the Brazilian Amazon. Environmental Research, 77: 73-78.

Markus J.; McBratney A. 2001. A review of the contamination of soil with lead II. Spatial distribution and risk assessment of soil lead. Environmental International, 27: 399-411.

Matheron G. 1971. The theory of regionalized variables and its applications. Paris, Le Cahiers du Centre de Morphologie Mathematique de Fontainebleu. Ecole des Mines de Paris, Fascicule 5, Fontainebleau, 1971.211 p.

Maurice-Bourgoin L.; Alanoca L.; Fraizy P.; Vauchel P. 2003. Sources of mercury in surface waters of the upper Madeira erosive basins, Bolivia. Journal Physique IV France, 107: 855 - 856.

Meade R.H.; Dunne T.; Richey J.E.; Santos U.M.; Salati E. 1985. Storage and remobilization of suspended sediment in the lower Amazon river of Brazil. Science; 228: 488490.

Pfeiffer W.C.; Lacerda L.D. 1988. Mercury inputs into the Amazon region, Brazil. Environmental Technology Letters, 9: 325-330.

Pfeiffer WC, Lacerda LD, Malm O, Souza C, Silveira EG, Bastos WR. 1989. Mercury concentrations in inland waters of gold-mining areas in Rondônia, Brazil. Science of the Total Environment, 88: 233-240.

Pfeiffer W.C.; Malm O.; Souza C.M.M.; Lacerda L.D.; Silveira E.G.; Bastos W.R. 1991. Mercury in the Madeira river ecosystem, Rondonia, Brazil. Forest Ecology Management, 38: 239 -245.

Roulet M.; Lucotte M.; Farella N.; Serique G.; Coelho H.; Sousa Passos C.J.; Jesus S.E.; Scavone A.P.; Mergler D.; Guimarães 
J.R.D.; Amorim M. 1999. Effects of recent human colonization on the presence of mercury in Amazonian ecosystems. Water Air and Soil Pollutant, 112: 297 - 313.

Roulet M.; Lucotte M.; Canuel R.; Farella N.; Courcelles M.; Guimarães J.R.D.; Mergler D.; Amorim M. 2000. Increase in mercury contamination recorded in lacustrine sediments following deforestation in the central Amazon. Chemistry Geology, 165: 243-266.

Roulet M.; Guimarães J.R.D.; Lucotte M. 2001. Methylmercury production and accumulation in sediments and soils of an Amazonian floodplain effect of seasonal inundation. Water Air and Soil Pollutant, 128: $42-60$.
Vergotti M.; Bonotto D.M.; Silveira E.G.; Bastos W.R. 2009. Influência da matéria orgânica na adsorção de $\mathrm{Hg}$ e outros elementos em sedimentos de lagos da bacia do rio Madeira (RO). Geochimica Brasiliensis, 23: 91 - 100.

Watras C.; Bloom N. 1992. Mercury and methylmercury in individual zooplankton - implications for bioaccumulation. Limnology Oceanography, 37: 1313-1318.

Recebido em 15/12/2012

Aceito em 03/06/2013 
